\title{
Perubahan Struktural Fungsional Prostitusi Online dalam Pandangan Talcott Parsons
}

\author{
Zainal Fadri' ${ }^{1}$ \\ Institut Agama Islam Negeri Batusangkar
}

\begin{abstract}
Online prostitution was uncovered after it was discovered that several social media accounts provided sex services that were easily accessible and at varying prices. The emergence of online prostitution has been reported as a form of resistance by some prostitutes in getting customers due to the closure of many localized places as centers of sexual transactions. Far from that, online prostitution has a troubling impact on the local community, especially for young people who are still at puberty, many of whom have fallen into the form of prostitution. This paper highlights the functional changes of prostitution that are offered with internet access and social media as functional changes in prostitution relations so that efforts are made to find the root of the problem in online prostitution. The method used in this writing is descriptive qualitative, namely by reading the supporting literature and by following the news about the development of online prostitution. The results obtained are that online prostitution is not pure prostitution for economic reasons, but rather refers to the concept of trends and lifestyles, so that the changes seen in online prostitution are structural changes in prostitution as well as irregularities in prostitution behavior that can be said as deviant behavior or pathological behavior.
\end{abstract}

Keywords: online prostitution, functional structural changes, pathological behavior

\begin{abstract}
Abstrak
Prostitusi online menguak setelah ditemukan beberapa akun-akun sosial media menyajikan jasa-jasa pelayanan seks yang dapat diakses dengan mudah dan dengan penawaran harga bervariasi. Munculnya prostitusi online dilansir sebagai bentuk perlawanan sebagian pelaku prostitusi dalam mendapatkan pelanggan karena banyaknya penutupan tempat-tempat lokalisasi sebagai pusat transaksi seksual. Jauh dari pada itu, prostitusi online memiliki dampak yang meresahkan bagi masyarakat setempat terutama bagi kalangan pemuda yang masih dalam masa pubertas, banyak diantara mereka yang terjerumus dalam bentuk praktek prostitusi. Tulisan ini menyoroti perubahan fungsional prostitusi yang ditawarkan dengan akses internet dan media sosial sebagai perubahan fungsional dalam relasi prostitusi sehingga diupayakan menemukan akar persoalan pada prostitusi online. Metode yang digunakan dalam penulisan ini adalah deskriptif kualitatif, yakni dengan pembacaan literatur pendukung serta dengan mengikuti berita-berita mengenai perkembangan prostitusi online. Hasil yang didapatkan adalah bahwa prostitusi online bukan merupakan prostitusi murni dengan alasan ekonomi, namun lebih mengacu pada konsep trend serta gaya hidup, sehingga perubahan yang terlihat dalam prostitusi online adalah perubahan struktur dalam prostitusi serta adanya penyimpangan-penyimpangan yang terdapat pada perilaku prostitusi yang dapat dikatakan sebagai perilaku menyimpang atau perilaku patologis.
\end{abstract}

Kata Kunci: prostitusi online, perubahan struktural fungsional, perilaku patologis

\footnotetext{
${ }^{1}$ zainalfadri@iainbatusangkar.ac.id
} 


\section{Pendahuluan}

Prostitusi online banyak diangkat sebagai isu hangat akhir-akhir ini. Penggerebekan dan penanganan kasus-kasus prostitusi online seolah-olah menjadi obrolan biasa di tengah hiruk pikuknya kehidupan masyarakat dalam menghadapi berbagai tantangan global. Banyak media-media yang tidak henti-henti memberitakan kasus-kasus prostitusi online, baik media cetak, media elektronik bahkan hingga akun-akun di sosial mediapun tidak mau kalah akan persoalan yang sedang booming di berbagai kalangan negara.

Isu-isu yang beredar mengenai prostitusi online banyak menyita perhatian dari berbagai kalangan, mulai dari masyarakat biasa, kalangan selebritis, politisi bahkan sampai kalangan alim ulama sekalipun. Berita yang tersebar mulai mengangkat pelaku-pelaku yang terlibat dalam kasus prostitusi, yang diwarnai oleh kalangan artis, model maupun mahasiswa dengan tarif yang fantastis hingga ratusan juta rupiah. Prostitusi online menjadi suatu kasus yang berdampak bagi masyarakat dan kehidupan yang dijalani. Kasus prostitusi online menjadi sorotan yang menarik untuk dilihat lebih lanjut mengenai persoalan yang sesungguhnya terjadi.

Persoalan yang ada dalam kasus prostitusi online merupakan model perubahan yang berjalan dalam kehidupan sebagian masyarakat yang sangat berhubungan erat dengan kemajuan teknologi komunikasi dan informasi. Perubahan yang terjadi akan meliputi model-model atau corak-corak serta dampak dari perilaku prostitusi online terhadap model dan tata hubungan masyarakat sehingga tidak jarang menimbulkan konflik yang menjadikan kehidupan masyarakat menempuh fase-fase pergolakan, baik dari segi tradisi maupun pola interaksi serta hubungan sosial. Dalam kasus prostitusi online akan dilihat perubahan struktur dan perubahan fungsional yang dikemukakan Parsons dengan berbagai argumen dan analisis sehingga terlihat bahwa telah terjadi suatu pergeseran atau perubahan dalam relasi hubungan prostitusi, baik terhadap perilaku prostitusi maupun terhadap masyarakat luas. Penelusuran perubahan fungsional dalam relasi prostitusi online dengan melihat perubahan yang ditimbulkan diupayakan sebagai bentuk dini dalam melihat akar permasalahan dari merebaknya prostitusi online, sehingga diharapkan membantu untuk menangani dan menanggulangi permasalahan prostitusi dan prostitusi online secara khusus yang meresahkan kehidupan masyarakat.

Penelitian mengenai prostitusi online sudah menjadi perhatian para peneliti dan pemangku kepentingan semenjak menguaknya kasus-kasus yang ditemukan oleh pihak kepolisian sehingga persoalan ini menjadi hal yang harus mendapat kajian dari berbagai disiplin keilmuan. Dari penelusuran yang dilakukan belum ditemukan penelitian yang memfokuskan pada perubahan struktural dalam prostitusi online dan secara khusus dibahas dengan teori Talcott Parsons, sehingga penelitian ini dapat dikatakan merupakan penelitian yang segar dan dijamin orisinalitasnya.

Dari latarbelakang persoalan yang dikemukakan di atas, dapat dirumuskan menjadi beberapa rumusan masalah. Rumusan masalah pada tulisan ini adalah: (1) Bagaimana perkembangan prostitusi menjadi prostitusi online? (2) Apa pokok pemikiran Parsons mengenai perubahan sosial struktural fungsional? (3) Apa saja perubahan struktural fungsional yang terdapat pada kasus prostitusi online?. 


\section{Metode Penelitian}

Penelitian ini menggunakan metode kualitatif deskriptif dengan pendekatan literatur review. Metode kualitatif digunakan untuk menggali informasi lebih mendalam sehingga menjawab pertanyaan mengenai perubahan struktural yang terjadi dalam persoalan prostitusi. Sumber data dibagi menjadi dua bagian yaitu sumber data primer dan sumber data sekunder. Sumber data primer didapatkan dari penelusuran literasi berupa buku, jurnal ilmiah nasional dan internasional, maupun dari penelitian lain yang mendukung analisis penelitian dan memperkaya khasanah penelitian. Data sekunder pada penelitian ini menggunakan artikel dan dokumentasi media-media yang membahas masalah penelitian.

Keabsahan data-data penelitian dilakukan dengan metode triangulasi. Pertama dilakukan triangulasi sumber, triangulasi data dan triangulasi metode. Teknik analisis data pada penelitian ini dilakukan dengan penggalian informasi dari buku, jurnal dan pemberitaan media dilakukan klasifikasi kemudian dilakukan penarikan kesimpulan sehingga menemukan suatu hasil penelitian kemudian dituliskan dalam bentuk sebuah laporan penelitian berupa artikel jurnal. Pengayaan data juga dilakukan dengan wawancara dan observasi melalui media sosial yang digunakan oleh informan penelitian.

\section{Hasil dan Pembahasan \\ Prostitusi Online}

Prostitusi atau pelacuran memiliki usia yang sangat tua jika melihat dari sejarah peradaban manusia. Pelacuran dan prostitusi sudah ada semenjak manusia mengalami proses interaksi yang mengakibatkan adanya suatu hubungan kekerabatan serta hubungan saling pemenuhan kebutuhan dalam kelangsungan hidup sehari-hari. Prostitusi atau pelacuran dipahami sebagai bentuk fenomena dari implikasi hubungan antara manusia dalam menjalin kedekatan dan bentuk yang lebih spesifik. Prostitusi terjadi karena adanya kebutuhan hasrat yang berlebih dari salah satu manusia berinteraksi ataupun beberapa kalangan kemudian mencari pelampiasan untuk hasrat tersebut. Pelampiasan ataupun penyaluran hasrat berlebih yang tidak sesuai dengan pola dan tatanan masyarakat tertentu atau dengan pola hubungan suami istri yang sah menyebabkan banyak kalangan mencari jalan pintas untuk sekedar memenuhi hasrat (Kartono, 2014: 208). Pemenuhan hasrat seksual yang kurang tepat dicurigai sebagai awal dari munculnya kegiatan-kegiatan prostitusi.

Berbicara mengenai prostitusi tidak terlepas dari berbicara mengenai seks dan profit atau keuntungan dalam bentuk benda bernilai. Seks merupakan energi psikis yang mendorong manusia untuk aktif berperilaku dalam kehidupannya. Masalah seks sering menjadi persoalan dari alasan kehadiran prostitusi. Kalangan pelanggan prostitusi memiliki latarbelakang kurangnya penyaluran hasrat seksual dalam kehidupan dan bentuk hubungan sehingga mengakibatkan pemuasan di jalan lain yang lebih praktis menjadi pilihan bagi sebagian kalangan. Berbeda halnya dengan produsen atau pelaku yang menawarkan jasa prostitusi. Pelaku prostitusi biasanya melaksanakan kegiatan jual beli 
seks dengan alasan kebutuhan ekonomi yang mendesak sehingga jalan menjajakan diri merupakan suatu bentuk pilihan yang sangat mungkin pada saat itu.

Hubungan seksual dalam prostitusi tidak hanya mengenai persoalan berhubungan badan atau bersenggama (Kartono, 2014: 221). Kegiatan prostitusi juga dapat dilakukan dengan model kegiatankegiatan non-seksual. Kegiatan non-seksual berupa pemanjaan diri terhadap pelanggan sebagai bentuk penyaluran hasrat kasih sayang yang kurang dirasakan dalam hubungan rumah tangga, atau juga sebagai bentuk hubungan yang saling mendukung dalam berprestasi di bidang ilmu pengetahuan, seni, sosial, budaya dan lain sebagainya.

Permasalahan yang terdapat dalam prostitusi adanya hubungan atau relasi, baik seksual maupun non-seksual yang dilaksanakan dengan cara dan bentuk yang abnormal, yakni hubungan yang jauh dari kata normal. Hubungan dan relasi seksual yang normal meski tidak menimbulkan efek yang merugikan baik bagi perempuan maupun bagi pihak laki-laki, serta hubungan normal tidak menimbulkan konflik-konflik psikis dan tidak bersifat paksaan atau perkosaan. Baik pria maupun wanita mestinya menyadari batas relasi seksual yang normal dan etis menurut pandangan yang dianut oleh masyarakat sekitar sebelumnya dalam upaya menjamin kebahagiaan pribadi dan ketenangan serta ketenteraman masyarakat (Kartono, 2014: 223). Prostitusi digolongkan pada pola relasi yang tidak normal atau abnormal karena banyak mengandung konflik baik fisik maupun psikis serta sangat sarat dengan paksaan-paksaan yang merupakan suatu bentuk kekerasan dan penindasan.

Prostitusi memiliki beberapa jenis dari pola pendekatan serta model penawaran jasa pelayanan seks terhadap konsumen, yaitu prostitusi murni dan prostitusi terselubung. Prostitusi murni biasanya terdapat pada prostitusi atau model perdagangan seks dengan struktur yang lebih baik, seperti misalnya rumah-rumah bordil maupun pusat-pusat lokalisasi. Sementara prostitusi yang bersifat terselubung merupakan prostitusi dengan menyembunyikan identitas prostitusi di balik suatu identitas tertentu, misalnya prostitusi sebagai penjaga hotel, model, penyanyi, artis, pramugari dan lain sebagainya. Begitu juga halnya dengan prostitusi online. Prostitusi online dapat dimasukkan dalam kategori prostitusi terselubung, karena pelaku prostitusi online biasanya tidak menjadikan prostitusi sebagai pekerjaan pokok. Pelaku prostitusi online biasanya memiliki profesi lain sebagai model, mahasiswa, karyawan dan lain sebagainya. Prostitusi online menjajakan atau menawarkan jasa seks melalui akun-akun media sosial baik itu akun pribadi maupun dengan akun samaran, dengan harapan keuntungan yang banyak namun dengan modal yang minimum.

Prostitusi online yang marak saat ini membuat keresahan di kalangan masyarakat, karena kemudahan dalam mengakses prostitusi dan biaya yang ditawarkan cukup beragam. Banyak pelaku prostitusi online menawarkan harga yang sangat murah, sehingga dapat menjerumuskan para remajaremaja yang baru menginjak pubertas untuk menikmati fasilitas yang ditawarkan dengan harga murah. Namun, juga ada pelaku prostitusi online yang mematok harga lumayan tinggi, dan kebanyakan dengan target pelanggan politisi maupun pengusaha yang tentunya dengan servis dan keuangan yang lumayan besar. 
Prostitusi online yang merebak di kalangan masyarakat menggambarkan banyaknya penyebab-penyebab seseorang tenggelam dalam kasus prostitusi. Dapat dikatakan bahwa masyarakat begitu mudah mengakses layanan seks dengan harga yang terjangkau tanpa melihat dampak yang lebih serius dari hubungan seksual yang tidak sehat, diantaranya penyakit kelamin, retaknya hubungan rumah tangga serta banyaknya timbul konflik-konflik fisik maupun psikis yang akan terasa pada kemudian hari.

Praktek prostitusi atau pelacuran yang berkembang di masyarakat merupakan masalah yang kompleks dan rumit. Masalah prostitusi dapat menghambat pembangunan karena bertentangan dengan nilai-nilai sosial, norma agama dan kesusilaan, serta merendahkan martabat dan harga diri (Sihombing, 1996: 8). Tindakan pelacuran dapat mempengaruhi sendi-sendi kehidupan dan penghidupan masyarakat yang terlihat dari aspek ekonomi, budaya dan lain sebagainya. Prostitusi online disebut sebagai masalah yang rumit karena merupakan suatu model atau perilaku baru yang banyak dimunculkan sebagai bentuk implikasi dari prostitusi. Penanganan prostitusi online semakin menjadi sorotan publik karena mengandung masalah yang begitu rumit.

Pelacuran atau prostitusi online muncul karena banyaknya permasalahan prostitusi murni yang mengakibatkan kerugian serta ketidakpuasan pekerja seks atas keuntungan yang didapatkan karena semua pendapatan diatur oleh germo, sehingga banyak mereka yang keluar dari prostitusi murni dan berusaha sendiri menawarkan jasa seks secara mandiri via media sosial dan perangkat online lainnya. Kartono (2014: 243-244) mengemukakan penyebab terjadinya prostitusi secara umum karena: (1) Tidak adanya Undang-Undang yang melarang pelacuran secara eksplisit, dan tidak adanya aturan mengenai hubungan seks di dalam pernikahan maupun di luar pernikahan. (2) Adanya keinginan dan dorongan manusia untuk menyalurkan kebutuhan seks, khususnya di laur ikatan perkawinan. (3) Komersialisasi dari seks, baik pihak wanita maupun pihak germo ataupun konsumen serta oknum-oknum tertentu yang memanfaatkan pelayanan seks. Dapat dikatakan seks hanya dijadikan alat yang jamak guna untuk tujuan komersial di luar hubungan perkawinan. (4) Dekadensi moral, yaitu merosotnya norma-norma susila dan keagamaan pada saat menikmati kesejahteraan hidup sehingga menyebabkan pemutarbalikan nilai-nilai pernikahan sejati. (5) Semakin besarnya penghinaan masyarakat terhadap martabat kaum wanita dan harkat manusia. (6) Budaya eksploitasi pada zaman modern menyebabkan terjadinya praktek eksploitasi kaum lemah atau wanita dengan tujuan keuntungan profit dan komersil. (7) Adanya proyek-proyek pembangunan dan pembukaan daerah-daerah pertambangan dengan konsentrasi kaum pria, sehingga mengakibatkan ketidakseimbangan rasio antara wanita dan pria di daerah tersebut. (8) Adanya pertemuan budaya asing dengan kebudayaan daerah setempat yang mengakibatkan terjadinya perubahan-perubahan yang cepat dan signifikan sehingga menyebabkan keadaan masyarakat yang instabil. Keadaan masyarakat instabil menyebabkan kemungkinan banyaknya terjadi konflik ditambah kurangnya kontrol dari pemerintahan setempat dan pihak yang berwajib menyebabkan suatu keadaan yang kacau sehingga sangat memungkinkan tindakan prostitusi menyebar dengan cepat dan radikal. 
Permasalahan yang ditimbulkan oleh prostitusi online bukan sekedar menjadi persoalan biasa, karena luasnya lingkup serta pasar yang dihadirkan tidak mampu ditangkap secara eksplisit oleh pihak yang berwenang. Prostitusi online sering menjadi persoalan yang masih menjadi perdebatan di kalangan ahli sosial maupun ahli hukum. Perdebatan terjadi karena prostitusi online lebih mengarah pada persoalan manusia secara personal atau bisa dikatakan sebagai masalah dalam penyalahgunaan teknologi. Berbeda halnya dengan pelacuran dengan struktur germo yang memiliki permasalahan kemanusiaan, kekerasan serta paksaan. Meskipun demikian prostitusi online tetap memiliki dampak yang besar layaknya prostitusi yang lain.

Kartono (1976: 69-76) mengemukakan beberapa akibat dari perbuatan prostitusi diantaranya: (1) Prostitusi dapat menimbulkan dan menyebarluaskan penyakit kulit dan kelamin. (2) Merusak sendi-sendi kehidupan rumah tangga. Suami-suami yang tergoda oleh pelacur biasanya akan melupakan fungsi serta perannya sebagai kepala keluarga, sehingga keluarga menjadi berantakan harus ditanggung sebagai bentuk implikasi logis. (3) Mendemoralisasi atau memberikan pengaruh demoralisasi kepada lingkungan, khususnya anak-anak muda remaja pada masa pubertas. (4) Prostitusi memiliki korelasi dengan kriminalitas dan kecanduan bahan-bahan yang mengarah pada narkotik serta obat-obatan terlarang. (5) Merusak sendi-sendi moral, susila, hukum dan agama. (6) Adanya praktek eksploitasi manusia oleh manusia lain. Pada umumnya wanita-wanita prostitusi hanya menerima upah yang tidak sesuai dengan pengorbanan yang dilakukan. Seperti banyaknya dampak dan penyakit yang ditimbulkan oleh hubungan seksual hanya dihargai dengan sedikit uang, bahkan tidak jarang konsumen yang memperlakukan wanita prostitusi dengan kejam tanpa memberi imbalan yang sesuai. (7) Prostitusi dapat menyebabkan disfungsi seksual seperti impotensi, anorgasme, ejakulasi prematur dan lain sebagainya yang berhubungan dengan segala dampak bagi kegiatan prostitusi baik bagi wanita prostitusi sebagai penyedia jasa, maupun laki-laki sebagai konsumen hubungan seksual.

Prostitusi online mendapat perhatian khusus sebagai bentuk prostitusi model baru. Prostitusi online merebak begitu ekstrim di kalangan masyarakat menampilkan suatu bentuk perkembangan prostitusi yang pada awalnya berbentuk struktur eksplisit seperti lokalisasi maupun rumah bordil pelacuran menjadi usaha mandiri dengan penawaran online yang memungkinkan semua orang dapat bertindak sebagai pelaku penyedia jasa prostitusi maupun sebagai konsumen prostitusi hanya dengan modal kelihaian dalam memainkan media sosial online yang dimiliki, maka permasalahan baru yang serius mengenai prostitusi akan bermunculan sebagai implikasi dari lahirnya prostitusi online.

\section{Teori Perubahan Struktural Fungsional Parsons}

Parsons melihat kenyataan sebagai suatu yang bersifat umum dan luas yang tidak terpaku pada struktur sosial. Parsons seringkali menunjukkan suatu pendekatan dari teori mengenai tindakan yang bersifat umum. Sistem sosial dipahami sebagai sistem dari perspektif keseluruhan. Sistem budaya dan perubahan tradisi yang dialami masyarakat merupakan bentuk perubahan sistem yang seharusnya menjadi bentuk perubahan pada struktur masyarakat. Perubahan-perubahan struktur dan 
nilai yang terkandung dalam budaya dan tradisi akan menjadi bahan utama dalam melihat suatu gejala dan perubahan sosial terhadap suatu hal yang akan dijelaskan dalam bentuk pola relasi yang mengalami perubahan sehingga berakibat pada perubahan struktur dan fungsi.

Pemikiran Parsons lebih mengarah pada hubungan dan kesempatan yang termuat dalam bentuk relasi yang mengakibatkan adanya kemungkinan terjadinya suatu perubahan struktur sebagai dampak perubahan itu sendiri. Dalam penggunaan aspek-aspek tersebut, Parsons hanya menjadikan pola interaksi yang terjadi sebagai alat dalam melihat perubahan sosial (Johnson, 1996: 108). Interaksi yang dikemukakan dijadikan sebagai bentuk dan dasar pola perubahan yang terjadi di masyarakat sehingga akan menggambarkan pola perubahan budaya serta kebiasaan yang dipengaruhi oleh berbagai aspek seperti trend, ekonomis, sosiologis, dan lain sebagainya.

Parsons bukan berarti menyangkal pentingnya masalah perubahan. Parsons dalam karyanya menegaskan bahwa teori tindakan sama-sama memperhatikan persyaratan perubahan yang mustahil dapat dipelajari tanpa mempelajari teori perubahan pada aspek lain (Lauer, 1993: 109). Dalam melihat perubahan dan mekanisme perubahan harus diterangkan dengan kekuatan-kekuatan atau aspek-aspek yang dapat mempengaruhi perubahan yang terjadi, sehingga dapat dilihat faktor apa saja yang mempengaruhi serta bagaimana struktur yang mempengaruhi terjadinya suatu perubahan dalam pola struktural dan pola fungsional.

Sistem sosial adalah sejenis sistem individu yang berinteraksi, masing-masing individu atau kelompok-kelompok kecil mencoba mendapatkan kepuasan dirinya secara maksimum dalam suasana budaya tertentu. Pada dasarnya individu dalam sistem sosial tertentu berusaha mengejar kebahagiaan dengan alat yang mampu untuk mencapainya. Dalam pemikirannya, Parsons mengemukakan variabelvariabel serta pola yang memperlihatkan model dikotomi yang harus dilalui oleh seseorang secara eksplisit maupun implisit. Pilihan-pilihan yang dapat diambil individu dapat berupa efektivitas versus netralitas afektif, orientasi-diri (self-orientation) versus orientasi kolektif, universalisme versus partikularisme, askripsi versus prestasi (achievement), dan spesifitas versus kekaburan (diffuseness) (Parsons, 1951: 77).

Pola-pola pengembangan teori sosial struktural-fungsional dilakukan dengan menganalisa variabel-variabel serta bentuk hubungan antara orientasi individual terhadap yang lain yang tergabung dalam bentuk sebuah relasi atau hubungan. Dinamika suatu hubungan sosial akan mencerminkan suatu orientasi timbal balik antar individu. Hal ini terlihat dalam konsep interaksi yang terdapat pada pola hubungan dan keterlibatan seluruh individu sebagai anggota kelompok yang menghasilkan pola pertukaran untung-rugi dalam perspektif perbandingan. Pola relasi dan interaksi terlihat sebagai pola hubungan sosial sebagai bentuk perubahan sosial.

Pola relasi sosial yang mengalami perubahan dikatakan sebagai sistem sosial. Parsons mengemukakan bahwa interaksi variabel akan menimbulkan keinginan dan kebutuhan dalam menjalani kehidupan yang berujung pada tahap relasi kebutuhan dan terjalinnya hubungan dalam karya (Johnson, 1996: 122). Terjalinnya kebutuhan dalam karya antara pihak yang membutuhkan 
karya (sebagai konsumen) dengan pihak yang menciptakan karya (sebagai produsen) menyebabkan bentuk hubungan saling ketergantungan yang akan bertambah luas sebagai bentuk relasi kebudayaan maupun tradisi dalam kehidupan masyarakat tertentu. Pola hubungan masyarakat disertai dengan percampuran terhadap budaya baru atau budaya pendatang menyebabkan adanya penyesuaian terhadap budaya setempat sehingga memungkinkan terjadi pengaruh dan perubahan terhadap pola budaya yang akan berdampak bagi kehidupan masyarakat.

Perubahan pola hubungan di masyarakat menjadi landasan utama bagi perubahan sosial yang dikemukakan berdasarkan fungsional dan struktural. Perubahan sosial terlihat dalam berbagai proses relasi hubungan budaya dengan budaya lain yang mengharuskan adanya struktur-struktur institusi tertentu yang ada di masyarakat. Pola-pola institusional yang diperlukan di masyarakat adalah (Levy dalam Johnson, 1996: 126): (1) Struktur kekerabatan, struktur yang berhubungan dengan pengaturan ungkapan perasaan seksual, pemeliharaan dan pendidikan anak muda. (2) Struktur prestasi instrumental dan stratifikasi, struktur dalam masyarakat sebagai bentuk penghargaan atau prestasi atas tugas yang diselenggarakan dengan tujuan mempertahankan kesejahteraan masyarakat secara keseluruhan. (3) Teritorialitas, kekuatan dan integrasi sistem kekuasaan, bentuk organisasi masyarakat dalam upaya kontrol konflik internal yang berhubungan dengan masyarakat lainnya. Organisasi masyarakat ini dapat berbentuk organisasi sosial maupun organisasi politik. (4) Agama dan integritas nilai, memberikan kerangka kepercayaan dasar pada masyarakat sebagai suatu tatanan yang memiliki aturan-aturan dan batasan-batasan yang sesuai dengan kepercayaan yang dianut, sehingga memungkinkan keteraturan dalam relasi dan pola komunikasi dalam kehidupan masyarakat.

Perubahan struktur dalam masyarakat dapat dilihat secara kasat mata maupun dengan penelusuran lebih lanjut dengan cara dan tahapan yang lebih komprehensif. Untuk melihat tahapan yang komprehensif, perubahan sosial dilihat berdasarkan pola dan susunan dari beberapa aspek yaitu adaptation, goal attainment, integration dan latensi (Johnson, 1996: 130-131) atau sering dikenal dengan konsep A-G-I-L. (1) Adaptation, menunjukkan sistem sosial pada keharusan terhadap penyesuaian lingkungan dan masyarakat terhadap perilaku individu yang menuntut pada suatu bentuk susunan dan penyesuaian terhadap tuntutan dan kenyataan yang sedang dihadapi. (2) Goal attainment, persyaratan fungsional yang menggiring pada pernyataan dan sikap atas tujuan-tujuan bersama dalam suatu sistem sosial. Tujuan sistem sosial memusatkan tindakan pada kegiatan penyesuaian persiapan dalam mencapai tujuan tertentu. (3) Integration, pernyataan hubungan interelasi yang menghubungkan anggota dalam bentuk sistem sosial. Hubungan sistem sosial dan interelasi mengacu pada terciptanya hubungan emosional solidaritas dan bekerjasama sebagai bentuk dari tujuan perkembangan relasi kolektif. (4) Laten pattern maintenance, konsep latensi yang menunjukkan berhentinya interaksi dikarenakan kejenuhan dan keletihan yang tergambar dari anggota kelompok terhadap sistem sosial dan keterlibatannya dalam sistem tersebut. 
Konsep A-G-I-L mengembangkan suatu konsep hierarki dari suatu perubahan sosial yang mengacu pada susunan dan urutan terjadinya suatu fenomena perubahan sosial. Perubahan akan terjadi apabila suatu kondisi sistem sosial berada pada kondisi latensi yang akan berdampak pada keinginan anggota untuk mencari bentuk kondisi yang diyakini lebih menyejahterakan, dan kondisi inilah yang memunculkan adanya reaksi dan kontrol budaya serta nilai-nilai yang tertanam pada suatu kelompok masyarakat. Kontrol budaya terhadap pergolakan subsisten menjadi sistem sosial memperlihatkan perubahan sosial dijadikan sebagai model perkembangan masyarakat menjadi tujuan yang lebih baik, meskipun sering terjadi kerancuan dan kebocoran, seperti terciptanya pelanggaran nilai yang menimbulkan reaksi perilaku menyimpang atau perilaku patologis sebagai bentuk implikasi dari perubahan sosial fungsional dan struktural.

\section{Perubahan Struktural Fungsional Prostitusi Online}

Kasus prostitusi online menempati posisi yang memiliki masalah kompleks, sehingga memerlukan analisis dalam melihat konsep perubahan yang ada pada persoalannya. Kasus prostitusi online dilansir bukan saja dijalankan atas kondisi desakan ekonomi yang menjadikan seseorang rela menjual diri dengan menawarkan jasa pemuasan seks, karena pelaku penawaran jasa seks prostitusi online kebanyakan berasal dari keluarga yang memiliki kemampuan ekonomi serta memiliki basis pendidikan yang cukup. Merebaknya prostitusi online merupakan fenomena baru dalam model perubahan sosial dari pola prostitusi murni atau melalui instansi germo.

Perubahan struktur pada prostitusi online dapat dilihat dengan tahapan-tahapan yang ada pada konsep A-G-I-L yang dikemukakan oleh Parsons. Perkembangan dan tingkatan A-G-I-L diupayakan sebagai analisa terhadap pernyataan dan fenomena dalam suatu sistem sosial (Johnson, 1996: 129), sehingga diharapkan ada gambaran jelas mengenai perubahan sosial yang terjadi. Analisis A-G-I-L pada prostitusi online dapat dilihat dalam tabel berikut:

\begin{tabular}{|l|l|}
\hline Adaptation & $\begin{array}{l}\text { Pada awal kemunculan prostitusi merupakan bentuk adaptasi dari kesulitan yang } \\
\text { dihadapi oleh anggota masyarakat dalam menjalankan kehidupan sehari-hari. Bagi } \\
\text { mereka yang terhimpit ekonomi (terutama wanita rentan) akan melakukan berbagai } \\
\text { hal dalam mendapatkan mata pencaharian agar terpenuhinya kehidupan, sehingga } \\
\text { tidak jarang yang terlibat kasus prostitusi karena tingginya taraf depresi yang } \\
\text { melanda. Prostitusi dijalankan dengan bentuk penyesuaian terhadap model } \\
\text { pekerjaan baru, sehingga banyak dari pelaku prostitusi yang bertahan atau bahkan } \\
\text { keluar karena proses adaptasi dengan lingkungan pelacuran yang begitu kompleks. }\end{array}$ \\
\hline $\begin{array}{l}\text { Goal } \\
\text { attainment }\end{array}$ & $\begin{array}{l}\text { Pelaku prostitusi menjalankan penawaran jasa pemuasan seks kepada para } \\
\text { pelanggan dengan harapan tercapainya kebutuhan ekonomi sehingga kehidupan } \\
\text { menjadi layak dan terpenuhi dengan baik. Kondisi ini memperlihatkan tujuan dari } \\
\text { pelaku prostitusi untuk mendapatkan keuntungan demi kelangsungan hidup. }\end{array}$ \\
\hline Integration & $\begin{array}{l}\text { Pelaku prostitusi menjamin keamanan dengan adanya ikatan emosional dengan } \\
\text { germo ataupun dengan konsumen pelayanan seks, dengan harapan terciptanya } \\
\text { suatu pola hubungan dan relasi yang akan menjadi landasan serta daya tahan untuk } \\
\text { serangan dari pihak luar, seperti kekerasan dan premanisme di luar koridor instansi } \\
\text { germo. Pada tahap integrasi, pelaku prostitusi berada pada keadaan klimaks yang } \\
\text { menjadikan prostitusi sebagai model atau trend gaya hidup. Berbeda dengan } \\
\text { tahapan adaptasi yang memiliki tujuan sebagai bentuk survival, tapi hidup mewah } \\
\text { dan perilaku hiperkonsumtif. }\end{array}$ \\
\hline
\end{tabular}




\begin{tabular}{|l|l|}
\hline $\begin{array}{l}\text { Later pattern } \\
\text { manitent }\end{array}$ & $\begin{array}{l}\text { Pelaku prostitusi menemukan titik jenuh dalam kegiatan pelayanan seks. } \\
\text { Kejenuhan dapat berupa adanya konflik-konflik dan kompleksnya persoalan yang } \\
\text { terdapat dalam instansi germo sehingga mengakibatkan datangnya keinginan } \\
\text { pelaku prostitusi untuk membebaskan diri dari ikatan dan interaksi germo ataupun } \\
\text { dengan pelaku lain. Pada kondisi ini peran pelaku prostitusi terlihat dominan } \\
\text { sebagai awal terbentuknya perubahan sebagai reaksi dan keinginan bebas dari } \\
\text { ikatan. Keinginan terlepas dari ikatan germo dan pelaku lainnya dilansir sebagai } \\
\text { keinginan pelaku prostitusi untuk melakukan kegiatan prostitusi secara mandiri } \\
\text { yang lebih bebas. Salah satu bentuk prostitusi mandiri adalah dengan } \\
\text { memanfaatkan teknologi komunikasi berupa media sosial yang menjamur dengan } \\
\text { sebutan prostitusi online. }\end{array}$ \\
\hline
\end{tabular}

Perubahan prostitusi murni menuju prostitusi online memiliki tahapan dan persoalan yang dilalui oleh pelaku prostitusi. Keinginan untuk mandiri menjadi salah satu dasar yang sangat kuat bagi prostitusi murni (dengan ikatan germo) merambah pada prostitusi mandiri (dengan menggunakan media sosial sebagai pasar penawaran jasa pelayanan seks). Perubahan terjadi karena ketidaknyamanan pelaku prostitusi terhadap aturan dan kekangan yang diberikan oleh pihak germo sebagai pengelola keuntungan yang didapatkan oleh pelaku prostitusi.

Perkembangan prostitusi menjadi prostitusi online memiliki suatu persoalan individual yang harus menjadi sorotan. Pelaku prostitusi beralih pada prostitusi online dengan alasan keuntungan profit. Keuntungan profit memperlihatkan bahwa prostitusi tidak lagi menjadi jalan survival bagi wanita rentan dalam menghadapi sulitnya himpitan ekonomi, namun lebih mengarah pada gaya konsumtif yang memaksa wanita-wanita prostitusi lebih giat dalam mencari profit.

Perubahan semacam ini menjadi suatu fenomena penyakit sosial atau penyimpangan terhadap aturan yang berlaku di masyarakat. Banyaknya selebritis dan model yang terlibat dalam kasus prostitusi online merupakan bentuk nyata bahwa prostitusi online tidak berorientasi pada survive. Tingginya tawaran dan harga yang disampaikan dalam iklan dan media-media sosial semestinya memperlihatkan bahwa trend atau strata seorang pelaku prostitusi akan berubah dan hal itu menjadi ajang dalam memperlihatkan eksistensinya sebagai pelaku prostitusi. Trend dan gaya hidup yang ditunjukkan menjadi perbincangan yang meresahkan masyarakat dalam kehidupan dan interaksi dalam sistem sosial.

Prostitusi online menjadi kasus global yang menyerang generasi muda sebagai pemimpin masa depan. Merebaknya akun-akun media sosial yang sangat mudah diakses menjadikan ancaman tersendiri atas rusaknya tatanan sistem sosial yang ada di masyarakat, maka diharapkan adanya penyelesaian serta pencegahan berkembangnya prostitusi online sebagai bentuk patologi sosial yang ada di lingkungan masyarakat. Upaya yang dapat dilakukan untuk memberantas kasus prostitusi online dapat dilaksanakan dengan pendekatan struktur institusional yang ada dalam masyarakat seperti yang diutarakan Johnson (1996: 126), yakni melalui pendekatan struktur kekerabatan, prestasi instrumentasi dan stratifikasi, teritorial dan integrasi, serta penanaman agama dan integrasi nilai. 
Selain pendekatan institusional, penyelesaian kasus prostitusi juga dilakukan dengan pendekatan individu atau person blame approach yang akan menyadarkan setiap pelaku prostitusi online terhadap pelanggaran yang dilakukan. Penanganan prostitusi online dapat dipecahkan dengan adanya regulasi yang ketat dan tegas mengenai penggunaan internet dan media sosial dalam hubungan sistem sosial, sehingga penyalahgunaan teknologi dapat menjadi klasifikasi sebagai bentuk pelanggaran yang diupayakan mendapat penyelesaian secara hukum oleh pihak-pihak yang berwenang. Selain regulasi, yang harus ditanamkan pada setiap jiwa adalah mengurangi gaya hidup hyper-konsumtif yang banyak digambarkan oleh kehidupan pelaku prostitusi online, sehingga keinginan dan angan-angan yang tinggi tidak menjebak diri pada kondisi kesulitan ekonomi yang memungkinkan terjatuh pada kaus prostitusi. Pencegahan dibarengi penanaman nilai-nilai moral masyarakat sebagai bentuk kontrol sosial atas pelanggaran dan perilaku patologis.

\section{Kesimpulan}

Prostitusi online merupakan suatu bentuk perubahan dan perkembangan prostitusi instansi germo dengan alasan kemandirian dalam berkerja. Pelaku prostitusi menawarkan jasa pelayanan seks melalui akun-akun media sosial dengan penawaran dan ketentuan yang berlaku. Bentuk kegiatan postitusi online mengedepankan profit yang diterima secara penuh tanpa adanya campur tangan germo dan pelaku prostitusi yang lain. Teori perubahan struktral-fungional Parsons melihat pada model perubahan sosial dari struktur yang dibangun dalam interaksi suatu sistem sosial. Interaksi sistem sosial mengalami suatu perubahan dikarenakan keinginan dan kebutuhan suatu kelompok yang berakibat pada reaksi terhadap sistem yang ada sehingga memugkinkan adanya perubahan struktur serta perubahan fungsi pada interaksi dan sistem sosial. Perubahan struktur pada kasus prostitusi online terlihat pada model struktur dalam menjalani bisnis pelayanan seks yang pada awalnya melalui instansi germo menjadi model mandiri melalui akun-akun media sosial. Perubahan fungsional tergambar dari perubahan tujuan prostitusi dari asas survival menjadi model gaya hidup dan trend konsumtif tingkat tinggi yang banyak menimbulkan reaksi dari masyarakat.

\section{Daftar Pustaka}

Aditya. L. E. (2016). Urgensi Kriminalisasi terhadap Pelacuran dalam Pembaharuan Hukum Pidana di Indonesia. Jurnal Ilmiah. Universitas Brawijaya.

Arsanti, Melinda. (2017). Penggunaan Media Sosial sebagai Sarana Prostitusi Online. E-Jurnal Ilmu Komunikasi, 5 (3).

Bungin, B. ed. (2009). Penelitian Kualitatif: Komunikasi, Ekonomi, Kebijakan Publik, dan Ilmu Sosial Lainnya. Edisi Pertama. Jakarta: Kencana Media Group.

Carolina, A. H. D. (2014). Perlindungan Anak yang Tinggal di Sekitar Lokasi Prostitusi terhadap Perilaku Seksual Anak. Jurnal Mahasiswa. Fakultas Hukum Universitas Brawijaya. 
Fadri, Zainal. (2019). Tabuik: Local Wisdom as an Alternative for Suppressing the Impact of Structural Change in Pariaman. Alfuad: Jurnal Sosial Keagamaan, 3(1). 97-109.

Fadri, Zainal. (2019). Upaya Penanggulangan Gelandangan Dan Pengemis (Gepeng) Sebagai Penyandang Masalah Kesejahteraan Sosial (PMKS) Di Yogyakarta. Komunitas, 10(1), 119.

Fadri, Zainal. (2020). Perubahan Sosial Masyarakat Muslim Pedesaan Pasca Kedatangan Kyai. Komunitas, 11 (2). 37-46.

Fadri. Zainal. (2020). Pembangunan Masyarakat Model Democratic Participatory. Alfuad: Jurnal Sosial Keagamaan, 4 (2). 27-39.

Fajarwati, S. R., Rahayuningsih, T., \& Murni, A. (2017). Dinamika Psikologis Mucikari Remaja pada Prostitusi Online. Psychopolytan, 1 (1).

Gayatri, P. A., \& Novy, I Wayan. (2019). Pertanggungjawaban Pidana Para Pihak yang Terkait dalam Prostitusi Online. Kertha Wicara: Journal Ilmu Hukum, 8 (3). 1-8.

Harahap, A. A., \& Parwata, I Gusti Ngurah. (2018). Tindak Pidana Prostitusi Online di Wilayah Hukum Polda Bali. Kertha Wicara: Journal Ilmu Hukum. 1-11.

Hartanto, D. A. (2015). Penanggulangan Prostitusi Online Perspektif Pembaharuan Hukum Pidana di Indonesia dan Hukum Islam. Prosiding Seminar Nasional Kebangkitan Teknologi. Kudus: Universitas Muria Kudus.

http://kaltim.prokal.co/read/news/253509-prostitusi-kelas-atas-intai- kaltim.html.

http://sulsel.pojoksatu.id/read/2016/09/12/kenalan-di-beetalk-sekali-kencanrp800-ribu-tapi-harus-dihotel-yah/

http://www.tribunnews.com/iptek/2014/11/18/aplikasi-beetalk-diunduh-tigajuta-kali (diakses 31 maret 2017) $\quad$ http://www.kompasiana.com/171717/alasan-wanita-muda-cantik-jadipsk 552976cc6ea834763e8b4577

https://www.merdeka.com/peristiwa/3-lokalisasi-di-samarinda-ditutup-tiap- $\quad$ psk-dapat-duit-rp-5juta.html

Johnson, Doyle P. (1996). Teori Sosiologi Klasik dan Modern. Jakarta: PT Gramedia.

Juita, S. R., et al. (2016). Reformasi Pertanggungjawaban Pidana pada Pelaku Prostitusi Online: Suatu Kajian Normatif. Jurnal Dinamika Sosial Budaya, 8.

Kartono, K. (1976). Psikologi Abnormal dan Patologi Seks. Bandung: ALUMNI.

Kartono, K. (2014). Patologi Sosial. Jakarta: PT Raja Gravindo Persada.

Kenedi, John. (2017). Wanita dan Prostitusi dalam Perspektif Al-Qur'an dan Hadis. El-Afkar: Jurnal Pemikiran Keislaman dan Tafsir Hadis, 6 (1).

Khumaerah, N. (2017) Patologi Sosial Pekerja Seks Komersial (PSK) Perspektif Al-Qur'an. Jurnal Al-Khitabah, 3 (3).

Kristiyanto, E. N. (2019). Jangkauan Hukum Nasional Terhadap Prostitusi Daring (State Law Coverage on Online Prostitution). Jurnal Penelitian Hukum De Jure, 19 (1).

Lauer, R. H. (1993). Perspektif tentang Perubahan Sosial (judul asli: Perspective on Social Change, terj. Alimandan, SU.). Jakarta: PT Rineka Cipta.

Listyani, R. H. (2017). Pencegahan Praktik Prostitusi Online Melalui Lembaga Sekolah dan Keluarga. The Journal of Society and Media, 1 (2).

Marpaung, L. (2008). Asas Teori Praktik Hukum Pidana. Jakarta: Sinar Grafika,.

Moleong, L. (2002). Metode Penelitian Kualitatif. Bandung: Remaja Rosdakarya.

Munawaroh, S. (2010). Pekerja Seks Komersial (PSK) di Wilayah Prambanan Kabupaten Klaten, Jawa Tengah. Dimensia: Jurnal Kajian Sosiologi, 4 (2).

Musahwi. (2013). Di Balik Pelarangan Negara Terhadap Prostitusi: Studi tentang Politik Kepentingan dalam Wacana Amoralitas Prostitusi dan Perlawanan Kaum Prostitusi di Parangtritis. Thesis. Universitas Airlangga.

Parsons, T \& Edward A. Shils. (1951). Toward A General Theory of Action. New York: Harper \& Row.

Prakoso, G., Purwanti, A., \& Wijaningsih, D. (2016). Kebijakan Pemerintah dalam Menanggulangi Prostitusi di Kabupaten Belitung Provinsi Bangka Belitung. Diponegoro Law Journal, 5 (4).

Putra, I Putu. D. A. S., \& Suardana, I Wayan. (2018). Pertanggungjawaban Pidana terhadap Pelaku Prostitusi Secara Online Melalui Sosial Media dan Whatsapp. Kertha Wicara: Journal Ilmu Hukum, 8 (8). 1-16. 
Rahardi, P. (2007). Hukum Kepolisian Profesionalisme dan Reformasi Polisi. Surabaya: Laksbang Mediatama.

Rahmawati, W. H. (2020). Pertanggungjawaban Pidana Pengguna Jasa Prostitusi Online. Media Juris, 3 (3).

Rumadi. (2017). Kajian Yuridis terhadap Tindak Pidana Prostitusi dengan Menggunakan Sarana Media Online. Jurnal Ilmiah Hukum Universitas Wisnuwardhana, 11 (1).

Sari, H. P. (2010). Upaya Penanggulangan Prostitusi Online Internet Berdasarkan Undang-Undang Nomor 11 Tahun 2008 tentang Informasi dan Transaksi Elektronik (ITE). Jurnal Komunikasi Massa, 3 (1).

Sihombing, G. (1996). Analisis dan Evaluasi Hukum tentang Penanggulangan Prostitusi dan Pencegahan Penyebaran HIV/AIDS, Badan Pembinaan Hukum Nasional, Departemen Kehakiman Republik Indonesia.

Tugas dan wewenang polri http://pospolisi.wordpress.com/2012/11/03/tugas-danwewenang-polri/

Ulfiah., \& Hannah, N. (2018). Prostitusi Remaja dan Ketahanan Keluarga. Tazkiya: Journal of Psychology, 6 (2).

World Bank. (2006). Development and the Next Generation: World Development Report 2007. Washington DC: The World Bank.

Yanto, Oksidelfa. (2016). Prostitusi Online sebagai Kejahatan Kemanusiaan terhadap Anak. Jurnal Lex et Societatis, 16 (2). 